\title{
NUEVOS CAMINOS, TERRITORIO Y PAISAJE EN LA COMARCA DE LA COSTERA (VALENCIA). LA MIRADA DE LOS VIAJEROS
}

\author{
NEW ROADS, TERRITORY AND LANDSCAPE IN LA COSTERA \\ REGION (VALENCIA). THE LOOK OF THE TRAVELLERS
}

\author{
ADRIÀ BESÓ ROS \\ Universitat de València
}

\section{RESUMEN}

Por sus condiciones físicas, el valle de la Costera ha sido históricamente un lugar de paso obligado en el itinerario que, desde la llanura litoral valenciana, se dirige al sur y al centro peninsular. A finales del siglo XVIII se construye una moderna carretera y a mediados del XIX entra en servicio el ferrocarril entre Madrid y Valencia. En este trabajo analizamos la relación que se establece entre los caminos y el paisaje, y cómo esta se ha reflejado en los escritos que los viajeros que, entre finales del siglo XVIII y a lo largo de todo el siglo XIX, recorrieron por carretera y ferrocarril el valle de la Costera. Sus relatos integran estas modernas obras públicas con la visión secuencial del paisaje que se obtiene a lo largo del viaje, donde se definen determinadas imágenes culturales.

Palabras clave: Historia de la obra pública, viajeros, carretera, ferrocarril, paisaje cultural. 


\begin{abstract}
For its physical conditions, La Costera valley has historically been a place of obligatory passage in the itinerary from the Valencian coastal plain to the south and peninsular center. At the end of the 18th century a modern road was built and the railway between Madrid and Valencia came into service in the middle of the 19th century. In this paper we analyse the relationship established between the roads and the landscape, and how this has been reflected in the writings of the travellers who, between the end of the 18th century and throughout the 19th century, travelled La Costera valley by road and rail. Their stories integrate these modern public works with the sequential vision of the landscape obtained along the journey, where certain cultural images are defined.
\end{abstract}

Keywords: Public works history, travellers, road, railway, cultural landscape. 


\section{INTRODUCCIÓN}

La historia de las obras públicas y la relación con su entorno han generado un rico y diverso legado cultural. Hasta los años ochenta del siglo XX el estudio de las infraestructuras lineales históricas se ha centrado básicamente en los principales hitos construidos definidos por las obras de fábrica más relevantes. Pero las nuevas líneas de investigación plantean abordarlo desde su linealidad y a una escala territorial "siendo esta la única forma de contextualizar la obra como hito o rótula de este corredor, y la única forma de conservar o valorar objetos u obras menos valiosas como parte del conjunto" . De esta manera los trabajos de Miguel Aguiló, Ignacio Español, José María Tordesillas o Javier Rodríguez Lázaro, han estudiado las relaciones que se establecen entre las vías de comunicación, el país o territorio por donde discurren y el paisaje construido. Por ello, los caminos, "a su decisiva contribución como elementos conformadores del país, añaden su papel como instrumentos de penetración en el territorio" 2 . En este sentido "permiten a los usuarios la experiencia de los paisajes que recorren antes de detenerse en los lugares de destino" 3 . También ofrecen la posibilidad de abandonar temporalmente el camino para adentrarse en lugares que pasarán a integrarse en ese paisaje itinerante del camino.

Desde esta nueva perspectiva, el estudio de las infraestructuras lineales históricas atiende tanto a las mismas vías como a las relaciones que se establecen con su entorno. Respecto a las primeras, se analizan su trazado y las obras de fábrica que se han conservado, que en muchos casos son escasas como consecuencia de las sucesivas ampliaciones o desdoblamientos realizados para adaptarlas a las necesidades de los nuevos tiempos. Pero frecuentemente, además de los proyectos y la documentación que generó su construcción, los únicos testimonios contemporáneos al momento de su creación que disponemos se centran en las imágenes y relatos de los viajeros, que nos permiten conocer la experiencia de su uso, los hitos construidos que llamaron su atención y la relación que se estableció con el paisaje circundante. Todos ellos contribuyeron a fijar imágenes que se van repitiendo en diferentes relatos, bien porque de forma espontánea coinciden en despertar la atención, o porque

1 AGUILAR CIVERA, I., Itinerarios históricos: el "Camino Real del Reino de Valencia", València, Cátedra Demetrio Ribes UVEG-FGV, 2008, p. 3.

2 AGUILÓ, M., "El paisaje de las Obras Públicas", en Estudios Geográficos, T. LXXI, n 269, 2010, pp. 601-632, p. 603.

3 ESPAÑOL ECHÁNIZ, I., "Los valores paisajisticos de la red local de carreteras", Revista de Obras Públicas, $n^{\circ} 3.478$, p. 32. 
el viajero se ha documentado con anterioridad en los escritos publicados por sus predecesores, lo que ayuda a retroalimentar las imágenes creadas.

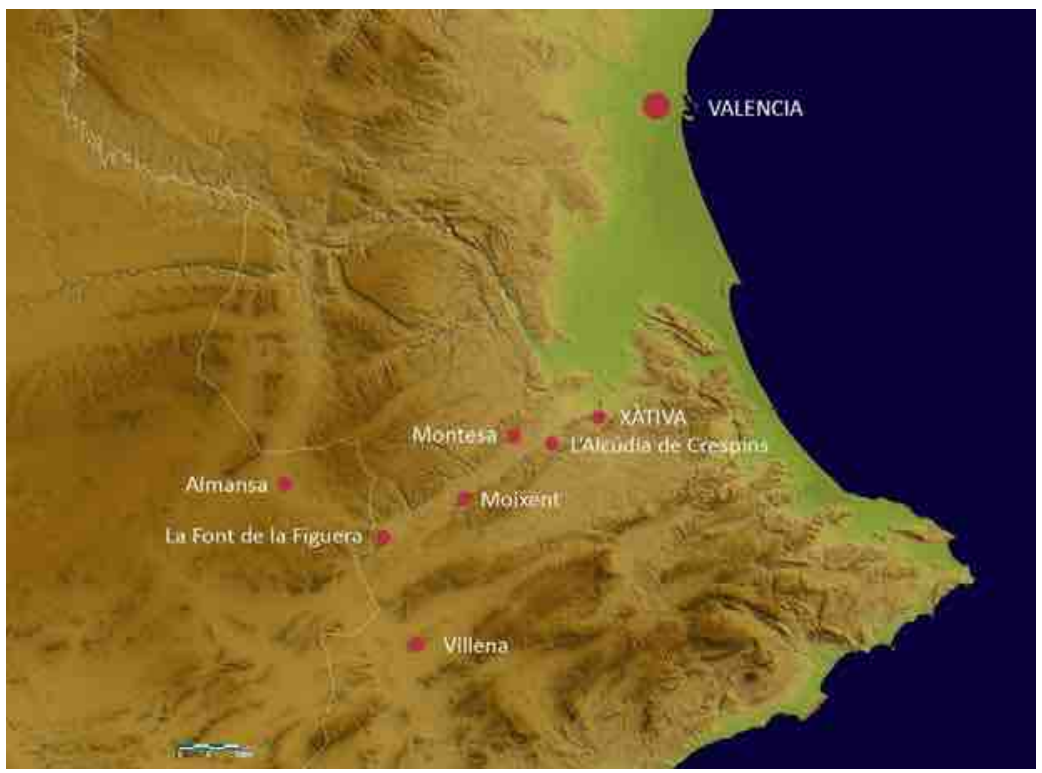

Fig. 1. Situación geográfica del valle que conforma el corredor de la Costera. Base cartográfica: Institut Cartogràfic Valencià. Elaboración propia.

Las condiciones geográficas del valle de la Costera fueron determinantes para atraer el paso de las primeras obras públicas modernas que comunicaban Madrid con Valencia ${ }^{4}$. Entre 1765 y 1778 se completó la construcción del

4 La comarca de la Costera está formada por un valle alargado de orientación bética SO-NE, que es el resultado de una falla de separación entre el sistema Ibérico, situado al norte (sierras del Cavalló y de Enguera), y los valles y sierras béticas del sur (sierra Grossa). Estas enmarcan una llanura de unos $50 \mathrm{~km}$ de largo entre la Font de la Figuera i Barxeta por unos cinco de ancho, que se cierra al oeste por la sierra del Caputxó, que marca el límite con la meseta manchega. Este corredor se ensancha a la altura de Canals en un valle que se divide en sentido este-oeste por las sierras del Castillo y de Bernissa, junto a la que se asienta la ciudad de Xàtiva, y queda delimitado al este por las elevaciones de Santa Ana y de la Cruz que marcan la divisoria con el valle aluvial del Júcar. La geología del terreno permite la formación de mantos freáticos que afloran en numerosos manantiales, cuyo caudal es recogido por los ríos Albaida Barxeta y Cànyoles, que confluyen en la llanura de la huerta de Xàtiva para desembocar junto al Júcar a la altura de Villanueva de Castellón. Los rasgos físicos que confluyen en el valle de Xàtiva, cuyo núcleo de población queda amparado por un imponente castillo que controlaba el paso de esta ruta de comunicación hacia el centro y sur peninsular, unido a la abundancia de agua, le otorgaron 
Nuevo Camino Real de Madrid a Valencia, concebido dentro de un plan de vías radiales con el que se inició la construcción de la red española de carreteras. Entre 1848 y 1859 se concluía la comunicación ferroviaria de la capital del Estado con Valencia. A partir de este contexto, el objetivo del presente trabajo se centra en conocer la percepción de estas obras públicas y de su paisaje circundante a través de los relatos de los viajeros. Para ello hemos tomado como fuente los libros de viajes publicados entre 1770 y finales del siglo XIX $^{5}$. La construcción del Nuevo Camino Real y posteriormente del ferrocarril, contribuyeron a convertir el corredor de la Costera en ruta de paso obligado desde la costa mediterránea hacia el centro y sur peninsular o en sentido inverso. Por ello, el número de referencias publicadas irá aumentando progresivamente durante toda la centuria en relación con un incremento del tránsito. A pesar de que prácticamente todos los viajeros dedican algunas notas a este trayecto, muchas veces son escuetas y responden a tópicos establecidos por autores anteriores que se copian sucesivamente. Por ello hemos seleccionado los testimonios que son más explícitos, descriptivos y originales.

En el primer punto presentamos las principales aportaciones de los nuevos caminos como obras de ingeniería modernas que responden a un proyecto, su relación con el territorio por el que se sobreponen y discurren, y la forma en que pueden ser percibidas por el viajero. Las carreteras modernas en un primer momento, y posteriormente el ferrocarril, fueron progresando en la implantación preferente de la línea recta y en una mayor presencia de las obras de fábrica, más abundantes y singulares por su novedad en el ferrocarril. Estas llamaron la atención de los primeros viajeros que las contemplaron y no escaparon a sus miradas, por lo que en sus relatos las presentaron de forma intercalada con las representaciones del paisaje circundante. Por ello, en los dos siguientes apartados abordamos estas imágenes producidas por los usuarios del Nuevo Camino Real de Madrid y del ferrocarril Madrid-Valencia a partir de sus expresiones escritas y gráficas.

en el pasado una función estratégica, por lo que se observa una continuidad en el poblamiento desde la época íbera hasta la actualidad.

5 Hemos podido localizar esta bibliografía, en su mayor parte digitalizada y accesible a través de internet, a partir de los repertorios publicados por GARCÍA-LÓPEZ ROMERAL PÉREZ, C., Biobibliografia de viajeros por España y Portugal (Siglo XVIII), Madrid, Ollero \& Ramos, 2000; y GARCÍA-LÓPEZ ROMERAL PÉREZ, C., Bio-bibliografia de viajeros por España y Portugal (Siglo XIX), Madrid, Ollero \& Ramos, 1999. 


\section{LOS NUEVOS CAMINOS Y SU RELACIÓN CON EL TERRITORIO Y EL PAISAJE}

Miguel Aguiló, tomando como referencia a Heidegger, afirma que para el ser humano construir es la manifestación del habitar, del ser en el mundo. Este habitar en el mundo no es estático, pues surge la necesidad de desplazarse, ya sea en el mismo entorno o a gran escala ${ }^{6}$. En este sentido explica que el camino es la obra pública por excelencia, pues constituye el espacio por donde se puede recorrer el mundo. Con su aparición se construye y se organiza el territorio, se convierte en agente de lo público desde donde se puede tener acceso a lo privado. El camino posibilita la percepción del mundo, pues permite llegar a otros lugares y contemplar y fijar imágenes del espacio que se percibe al discurrir por el mismo ${ }^{7}$.

Durante el Antiguo Régimen no existía una red de caminos estatales. Como afirma Nardiz, "no se tenía conciencia de la potencialidad ordenadora y estructuradora del territorio que podían tener las obras públicas en general, y el particular los caminos"8. Los itinerarios de larga distancia no eran más que la suma de pequeños caminos que unían poblaciones próximas, que eran mantenidos y administrados por los municipios que atravesaban. Se caracterizaban por su irregularidad, por la facilidad de adaptación a la morfología del relieve para evitar en la medida de lo posible las obras de fábrica y por las notables diferencias en su estado de conservación entre unos tramos y otros. Desde el siglo XVIII, con el establecimiento del Absolutismo y la difusión de la Ilustración, se volvía a plantear de nuevo esa voluntad de intervención y de ordenación sobre el territorio que caracterizó la red viaria romana. A diferencia de los anteriores, los nuevos caminos reales son fruto de un proyecto que responde a objetivos económicos y políticos: facilitar la libre circulación de mercancías y de personas que estimulara el comercio y el desarrollo económico, y a su vez establecer un control del territorio por parte de un Estado centralizado.

En relación con estos objetivos estratégicos, ya no pretendían relacionar unas poblaciones con otras, sino unir puntos lejanos con el menor recorrido y

6 AGUILÓ, M., Qué significa construir. Claves conceptuales de la ingeniería civil, Madrid, Abada, 2013, p. 13-14.

7 Ibídem, p. 35-36; AGUILÓ ALONSO, M., "El diseño de la carretera como acceso. Paisaje y monumento", en $2^{a}$ Congreso paisaje e infraestructuras. Libro de actas, Málaga, Junta de Andalucía. Consejería de Obras Públicas y Vivienda, 2010, pp. 17-34, p. 19.

8 NÁRDIZ ORTIZ, C., El territorio y los caminos en Galicia. Planos históricos de la red viaria, Madrid, Colegio de Ingenieros de Caminos, Canales y Puertos, 1992, p. 215.

9 CORONADO TORDESILLAS, J. M.; RODRÍGUEZ LÁZARO, F. J., "Geometrías de las carreteras y del territorio", Ingeniería y Territorio, $\mathrm{n}^{\circ} 84,2008$, pp. 48-55, p. 50. 
tiempo posibles, lo que se refleja en un cambio en su concepción y su morfología. Sus trazados buscan la línea recta y evitan las poblaciones cuando no es necesario pasar por ellas para lograr recorridos más directos ${ }^{10}$. Por ello, cuando se tropieza con un obstáculo que hay que salvar, se proyectan diversas alternativas de acuerdo con su naturaleza, como la realización de desmontes, construcción de terraplenes o de puentes. Cuanto más firme es el propósito de mantener la línea recta, más necesarias resultan estas intervenciones y su presencia se hace más visible sobre el territorio, por lo que el camino se percibe como algo claramente superpuesto, como un producto construido. $\mathrm{Y}$ a su vez, la línea recta desde la tracción animal permite que el viajero pueda desentenderse de prevenir los obstáculos del camino y facilita una percepción placentera del entorno, lo que hace su viaje más agradable ${ }^{11}$. Esta segunda circunstancia, favorecida por la presencia de obras de fábrica que posibilitan el trazado rectilíneo, ayuda a su vez valorar la relación de la obra pública con el territorio, por lo que este se percibe como paisaje construido.

Cuando la línea del camino se encuentra con obstáculos elevados, estos se pueden vadear adaptándose al relieve hasta que se alcanza la altura donde la traza debe penetrar inevitablemente en la montaña a través de una trinchera o de un túnel. En las primeras carreteras proyectadas, por su mayor facilidad de adaptación al terreno en comparación con el ferrocarril, se intentó prescindir de los túneles por su elevado coste y por los riesgos que entrañaba su construcción, por lo que siempre fue necesario alcanzar cotas más altas para atravesar las montañas. Cuando el obstáculo no es una elevación, sino un cauce o una depresión, el problema de extenderse en el camino se plantea de forma inversa. El trazado va descendiendo hasta que llega un punto en que la pendiente y el radio de la curvatura necesarios obligan a levantar artificialmente la carretera con la construcción de un puente o viaducto para poder alcanzar la vertiente opuesta ${ }^{12}$.

Para minimizar la confrontación con el obstáculo los caminos tienden a discurrir por terrenos suaves sin accidentes abruptos. Estas premisas explican que el corredor de la Costera, por sus características naturales, fuera el elegido para consolidar la vía de comunicación entre Madrid, Alicante y Valencia por carretera y ferrocarril, a pesar de su mayor longitud respecto a las otras alternativas más directas. El paso por un terreno con obstáculos naturales de menor consideración que los que encontramos en los trazados más cortos planteaba un importante ahorro económico en el momento de su construcción,

10 AGUILÓ, M., Op. cit., 2013, pp. 36 y 38.

11 ESPAÑOL ECHÁNIZ, I., Op. cit., 2007, p. 36.

12 AGUILÓ, M., Op. cit., 2013, p. 41. 
además de una mayor comodidad para los usuarios por el predominio de la línea recta en muchos de sus tramos.

El carril de hierro se introdujo para proporcionar mejor apoyo y un recorrido guiado al carro. Con el tiempo, gracias a la aplicación de la tracción mecánica, género la posibilidad de aumentar la velocidad, alcanzando los 40$50 \mathrm{~km} / \mathrm{h}$ frente a las velocidades habituales hasta el momento que no solían superar los $10 \mathrm{~km} / \mathrm{h}$. Puesto que la velocidad y la rapidez son objetivos del ferrocarril, su trazado no admite grandes pendientes ni curvas cerradas, por lo que se ajusta más difícilmente al terreno que la carretera y las obras de fábrica juegan un papel determinante ${ }^{13}$. Por ello, para evitar los grandes rodeos que se requieren en la carretera para salvar un obstáculo elevado, resulta mucho más efectiva y económica la construcción de un túnel. En este sentido, Miguel Aguiló afirma que la velocidad, introducida en el mundo del transporte por el ferrocarril, es la responsable directa en la proliferación y desarrollo de los túneles ${ }^{14}$. Estas mismas necesidades de mantener los radios y las pendientes dentro de los parámetros establecidos explican también la forma de abordar el paso del vado desde una mayor altura para evitar descensos y ascensos innecesarios, lo que se traduce en un aumento de las luces a cubrir por el puente. Para ello se experimentó con nuevas estructuras, primero de madera y posteriormente metálicas, mucho más ligeras, que terminaron por imponerse sobre los tradicionales puentes de fábrica.

La novedad de este medio de locomoción y de transporte que carecía de precedentes hizo necesaria la planificación de una red estatal, que en España fue construida y explotada mediante concesiones a compañías privadas. La implantación del ferrocarril durante el tercer cuarto del siglo XIX relegó a la carretera como medio desplazamiento para los viajeros, pues "frente al confort que puede ofrecer el tren, la diligencia y la carretera resultan lentas, peligrosas e incómodas"15. Por ello se van a servir exclusivamente del tren en los largos itinerarios y solo tomarán la carretera para llegar a aquellos destinos donde el ferrocarril no puede hacerlo. Así, la presencia de estos grandes ejes ferroviarios va a determinar la preferencia de unos trazados sobre otros, y en este caso contribuye decisivamente a la consolidación del corredor de la Costera. Si el Camino Real había marcado el inicio de la primacía de este itinera-

13 Ibídem, p. 48.

14 AGUILÓ, M., Túneles y viaductos para los caminos españoles, Madrid, ACS, 2004, p. 18. Estos primeros túneles conforman un importante legado de la historia de la técnica y de la ingeniería, tal como lo explica JUNCÁ UBIERNA, J. A., "Tunnel Heritage in Spain: Roots of the Underground", Tunnelling and Underground Space Technology, T. 13, nº. 2, 1998, pp. 131-141.

15 AGUILÓ, M., Op. cit., 2013, p. 48. 
rio, este se consolidaría con el trazado del ferrocarril en detrimento de otras alternativas. Por ello, a partir de ese momento el número de testimonios generados a su paso se incrementará considerablemente respecto a épocas precedentes.

\section{EL NUEVO CAMINO REAL DE MADRID A VALENCIA}

El itinerario que históricamente comunicaba Valencia con Almansa era el antiguo camino foral que desde la capital se dirigía hacia el sur, pasando entre otras poblaciones por Silla, Algemesí, Alzira, Carcaixent y Manuel, hasta llegar a Xàtiva. Desde allí partía otro camino hacia Alicante por Albaida, Cocentaina, Alcoi y Xixona. El camino foral continuaba desde Xàtiva por el corredor del Cànyoles y atravesaba las poblaciones de Vallada, Moixent y La Font de la Figuera hasta llegar a Almansa. Esta fue la vía que recorrieron los viajeros durante la Edad Moderna para comunicarse con el sur o el centro de la península ${ }^{16}$. Su estado era muy desigual, ya que su mantenimiento dependía de cada una de las poblaciones por donde pasaba.

Una de las principales actuaciones de la política ilustrada del centralismo borbónico fue la promulgación por parte de Carlos III del Real Decreto de 10 de junio de 1761 por el que se creaba una de una red de caminos reales de estructura radial que comunicaban Madrid, como capital del Estado, con las principales ciudades de la periferia. Esta conformó la red principal de España hasta la aprobación del Plan Nacional de Carreteras, un siglo después, en 1860. Entre los primeros proyectados se encontraba el Nuevo Camino Real de Valencia. Tal como se desprende de su trazado y características, responde claramente al resultado de una obra pública planificada por el Estado con un objetivo político. Se pretendía de reforzar el centralismo a partir de la abolición de determinados fueros y privilegios como consecuencia de la Guerra de Sucesión y de la promulgación de los decretos de Nueva Planta. La comunicación con Madrid se efectuó a través del paso de Almansa y no por la vía más corta y directa, que era el camino de las Cabrillas, posiblemente para no enfrentarse a las dificultades que suponía atravesar importantes accidentes geográficos ${ }^{17}$. Pero entre Silla y Vallada se apartó del camino foral para pasar por Alginet, l'Alcúdia i Alberic, alejándose de poblaciones destacadas como Alzira, por

16 ARCINIEGA GARCÍA, L., El saber encaminado. Caminos y viajeros por tierras valencianas de la Edad Media y Moderna, Valencia, Conselleria de Infraestructuras y Transporte, 2009, presenta un amplio y detallado estudio de los relatos de los viajeros que discurrieron por este antiguo camino foral.

17 Ver RIBOT GARCÍA, L. A., "La construcción del camino de Valencia en el siglo XVIII", Investigaciones históricas, $\mathrm{n}^{\circ}$ 1, 1979, pp. 175-230. 
donde se cruzaba el Júcar, o la misma ciudad de Xàtiva, lugar de paso natural entre las llanuras de la Ribera y la Costera. Agustín de Bethancourt, creador del Cuerpo de Ingenieros de Caminos, Canales y Puertos, en su calidad de Inspector General, redactó en 1803 un informe donde valoraba el Camino Real de Madrid a Valencia desde la óptica del ingeniero, como un "camino anchísimo, en lo general doble, y en partes tres veces más ancho de lo que debe ser un camino regular; terraplenes altísimos, muchos de ellos inútiles, y un sinnúmero de obras de un lujo extraordinario"18.

A pesar de las críticas de Bethancourt, fue una obra moderna para el momento, cuyas principales características no pasaron inadvertidas a los viajeros. Destacan la notable anchura de la calzada, que alcanzaba los 20 metros, y su trazado rectilíneo. Esta concepción precisó de una mayor inversión en su ejecución, pues obligaba a afrontar el obstáculo natural sin rodearlo, lo que llevó a realizar desmontes, terraplenes y numerosas obras de fábrica. Los pontones o puentes de pequeñas dimensiones para salvar los barrancos y cauces estrechos o las casetas de peones camineros, encargados de su mantenimiento, se proyectaron de forma seriada atendiendo a una concepción moderna de las obras públicas ${ }^{19}$.

Joseph Townsend (1739-1816) en su viaje realizado entre 1786 y 1787 lo describía como un "camino, bastante reciente, liso, bien pavimentado, muy recto" 20 . De camino hacia Valencia observa con gran admiración la enorme trinchera abierta para salvar la barrera del puerto de Càrcer, que separaba los valles de Xàtiva y del Júcar.

"Después de abandonar la llanura, tuvimos que atravesar nuevas montañas, que me dieron la oportunidad de admirar la paciencia y la constancia del es-

18 BETHANCOURT, A., "Estado actual de los caminos y canales de España, causa de sus atrasos y defectos y medios para remediarlos en adelante... 1803", Revista de Obras Públicas, n 5,1869 , pp. 55-56. Las obras de fábrica encarecieron considerablemente los presupuestos y entrañaron riesgos, por lo que se trataron de utilizar de forma contenida en las carreteras del siglo XIX. Cuando los costes de ejecución de los elementos requeridos podían ser elevados, se prefería adaptar los trazados al territorio, incluso a costa de proponer algunos rodeos. Por ello estas obras de los caminos reales fueron muy criticadas por los ingenieros del siglo XIX como lo hizo el mismo Bethancourt, cuyas valoraciones negativas contrastaron con las alabanzas de los viajeros extranjeros.

19 Para disponer de un conocimiento más detallado de los aspectos técnicos de las diferentes obras de fábrica, ver NÁRDIZ ORTIZ, C., "Las primeras carreteras modernas. El trazado y la construcción de los Caminos Reales en el siglo XVIII", en Actas del Primer Congreso Nacional de Historia de la Construcción, Madrid, 19-21 septiembre 1996, Madrid, I. Juan de Herrera, CEHOPU, 1996, pp. 375380; RIBOT GARCÍA, L. A., Op. cit. pp. 192-207 y AGUILAR CIVERA, I., Op. cit., pp. 33-37.

20 TOWNSEND, J., A journey through Spain in the years 1786 and $1787 . .$. To the agriculture, manufactures, commerce, population..., London, C. Dilly, 1791. Hemos tomado la cita de la traducción al castellano publicada bajo el título: Viaje por España en época de Carlos III (1686-1687), Madrid, Turner, 1988, p. 390. 
pañol. Están construyendo ahora una nueva carretera que parecen dispuestos sea recta y llana, a pesar de las irregularidades del terreno que ha de atravesar. Si se topan con un barranco profundo, lo rellenan; si es una colina lo que les impide el paso, la allanan. En un sitio vi que, para no desviarse un ápice de la línea recta, abrían un ancho y largo paso en la piedra caliza, a una profundidad de más de cincuenta pies. Su ambición no conoce límites, y parecen decididos a emplear todos sus esfuerzos para eliminar cualquier obstáculo que les impida alcanzar la perfección absoluta"21.

Wilhelm von Humboldt (1767-1835) relacionaba las buenas cualidades de la obra pública con la belleza del entorno por donde discurre:

"Esta no es sólo la más bonita de España, sino también extraordinariamente buena y la parte que hoy vimos es además muy agradable a la vista. Efectivamente, a ambas partes de la carretera hay una serie de montañas que aquí están más cubiertas de vegetación y son más agradables a la vista que en el resto de España, y hasta las montañas la llanura es rica en productos de toda especie, lo que hace muy hermosa la región de Valencia. Además de olivos, de los que hay muchos (de tal manera que acompañan al viajero desde Toledo hasta Francia) se encuentran ahora ya muchos algarrobos (caroubier en francés), unos árboles muy bonitos" ${ }^{22}$.

Unos años más tarde, Alexandre de Laborde (1773-1842) realizaba una apreciación similar:

"El Camino que es todavía más hermoso y sólido que los de Aranjuez, conduce hasta Valencia casi siempre en línea recta por calzadas y puentes construidos sobre barrancos, cuyas subidas y bajadas son muy suaves y casi insensibles. Sigue por entre dos cordilleras calcáreas, que se extienden casi en línea paralela por un espacio de seis leguas, cuyos intermedios son una serie de tierras cultivadas, y de inmensas selvas de olivos y algarrobos, de un golpe de vista agradable; y cuyo conjunto anuncia la actividad del labrador y la fertilidad del suelo. Aumenta este placer la vista de la montaña de la mano derecha, en gran parte plantada de árboles y arbustos, que de lejos parecen un musgo que verdea" 23 .

21 TOWNSEND, J., Op. cit., pp. 391-392.

22 HUMBOLDT, W., Diario de viaje a España 1799-1800, Madrid, Cátedra, 1998, p. 224.

23 LABORDE, A., Itinerario descriptivo de las provincias de España... traducción libre del que publicó en francés Alexandro Laborde, Valencia, Librería de Cabrerizo, 1826, pp. 65-66. Laborde viajó por España entre 1800 y 1805. Fruto de este viaje fueron las obras Voyage pittoresque et historique de l'Espagne, Paris, Pierre Diderot, 1806-1820, IV vols., obra ilustrada con 272 láminas en la que presta especial atención a los monumentos y a las antigüedades. Posteriormente publicó Itinéraire descriptif de l'Espagne..., Paris, N. H. Nicolle, 1808-1809, V vols, donde deja más de lado los monumentos para 
Históricamente el mantenimiento de la red principal de largo recorrido se dividía entre los municipios por donde discurría el camino. En 1762 se aprobó un Reglamento para conservación de los caminos en general (Real Cédula del 1 de noviembre de 1762), que contemplaba el establecimiento de los peones camineros, cuya función consistía en mantener en buen estado el tramo de una legua que tenían asignado ${ }^{24}$. Por ello, estas vías se dotaron de casillas de peones camineros, que se construyeron de forma seriada a partir de un modelo, repartidas a lo largo del camino. Townsend es el único viajero que alude a ellas con estas palabras:

"Al final de cada legua vemos una hermosa cabaña provista de huerto. En ella vivía el guardia del camino, que está encargado de defender al viajero y mantener la vía en buen estado, para lo cual dispone de las armas y herramientas necesarias. Su sueldo asciende a cinco reales al día, un chelín ${ }^{25}$.

Este nuevo camino pasaba por poblaciones muy alejadas del viejo camino foral, que era la principal ruta de comunicación, por lo que tuvo que dotarse de ventas y albergues para dar servicio a los viajeros. En el tramo de Xàtiva a la Font de la Figuera llegaron a haber 10 establecimientos, que fueron construidos por iniciativa real y también por parte de algunos nobles, señores territoriales de algunos pueblos por donde pasaba el camino ${ }^{26}$. De todas ellas, la de Rotglà y la del Marqués de la Romana fueron las más afamadas por los testimonios que nos han dejado los viajeros.

La posada del Rey de Rotglà, a 4 km de Xàtiva, fue construida por iniciativa de la Corona en 1786 a partir del proyecto de Manuel Serrano, director del Nuevo Camino Real de Madrid a Valencia ${ }^{27}$. Un año después, en 1787 se alojó en ella Joseph Towsend en su trayecto desde la Font de la Figuera, quien la llegó a valorar como una de las mejores de España, en la que:

centrarse más en la descripción de las regiones que atraviesa. El Itinerario descriptivo de las provincias de España... que hemos citado parte de la traducción de esta obra.

24 DE ORTUETA HILBERATH, E., "Modelos de casillas de peones camineros", en Actas del Tercer Congreso Nacional de Historia de la Construcción, Sevilla, 26-28 octubre 2000, Madrid, Instituto Juan de Herrera, SEdHC, Universidad de Sevilla, Junta Andalucía, COAAT Granada, CEHOPU, 2000 , p. 733.

25 TOWNSEND, J., Op. cit., pp. 390

26 PIQUERAS, J. y SANCHIS, C., Hostales y ventas en los caminos históricos valencianos, Valencia, Generalitat Valenciana, Conselleria d'Infraestructures i Transport, 2006, pp. 208-216 estudian las ventas construidas en el Nuevo Camino Real de Madrid. También Baños Oliver, R. y Segado Vázquez, F., "Ventas y posadas en el sureste español. La decadencia de una tipología arquitectónica", $3 C$ Tecnología. Glosas de Innovación a la pyme, 7 (3), 2018, pp. 50-69, presentan un estudio tipológico de su arquitectura.

27 PIQUERAS, J. y SANCHIS, C., Op. cit., pp. 212-214. 
"Sus excelentes camas disponían de jergones de paja, ropa blanca y colchones. Por la mañana para beber mi chocolate me trajeron una taza y un platillo de fina porcelana, que elaboran en la real fábrica del Buen Retiro a imitación de la francesa. Todos los precios están fijados y el administrador es sorprendentemente atento con los viajeros. Es sin duda la posada más confortable que he encontrado en España. Contiene catorce alcobas, una cocina para los arrieros, una espaciosa cochera, y establos con capacidad para treinta caballos, mulas o asnos ${ }^{28}$.

También llegó a pernoctar el mismo Carlos IV en 1803 y 1808. Laborde la calificó de "grande y hermoso edificio [...] en donde hay toda comodidad apetecible" 29 .

Otra venta nombrada e interesante por su arquitectura es la construida en Moixent por el Marqués de la Romana hacia $1795^{30}$. Uno de los primeros viajeros que la menciona es Wilhelm von Humboldt, quien en 1800 la valoraba como "un bello y espacioso edificio con una galería interior en el patio desde la cual se tiene una muy bella y amplia perspectiva. Por lo demás, como fonda no es mejor que cualquier otra venta"31. Unos años más tarde Alexandre Laborde la calificó de "palacio". Disponía de 15 habitaciones con grandes ventanales abiertos al exterior, desde donde "se descubre a la derecha el lugar de Vallada, y a la izquierda la villa de Montesa en forma de anfiteatro, con las ruinas de un antiguo castillo"32. El mismo autor se refiere también a las cercanas ventas de Moixent y de la Balsa, que califica de "muy cómodas $y$ de buena construcción" 33 . El mismo Laborde, nombra de viaje hacia Xàtiva la Venta del Conde, en el término de 1'Alcúdia de Crespins, edificada hacia 1790 por el Conde de Sumacàrcer ${ }^{34}$.

El camino ofrece una visión secuencial del entorno por donde discurre, cuya percepción viene facilitada por la lentitud de la tracción animal. Los diferentes viajeros suelen coincidir en las imágenes del paisaje que reflejan en sus escritos. Tras dejar la áspera meseta del Vinalopó y la llanura de Almansa, al atravesar la barrera de montañas de la sierra del Caputxó se percibe un cambio en el panorama. A la altura de Moixent, el valle por donde discurre el camino se ensancha progresivamente y se hace más fértil, hasta culminar en la

28 TOWNSEND, J., Op. cit., pp. 390

29 LABORDE, A., Op. cit., 1826, p. 67.

30 PIQUERAS, J. y SANCHIS, C., Op. cit., pp. 215-216.

31 HUMBOLDT, W., Op. cit, p. 224.

32 LABORDE, A., Op. cit., 1826, p. 66.

33 Ibídem.

34 LABORDE, A., Op. cit., 1826, p. 67. 
deliciosa y extensa huerta de Xàtiva como antesala de las grandes llanuras irrigadas por el Júcar y el Túria que acompañarán el viaje hasta Sagunt.

En su trayecto desde Almansa o desde Alicante, nada más tomar la carretera de Madrid a Valencia a la altura de la Font de la Figuera, los viajeros advierten un cambio en el entorno. Joseph Towsend explicaba:

"Desde esta deliciosa llanura accedimos enseguida a un reducido valle encerrado entre peñas calizas, en el que el paisaje cambiaba a cada paso. Todos los espacios llanos se encontraban cubiertos de trigo, cebada, centeno o maiz; las tierras altas producían olivos, higueras, vides; y los páramos escarpados, inservibles para el cultivo, estaban abandonados al romero, a la menta, a la lavanda y a la maravillosa adelfa, mientras que los altos pinos, que coronaban las rocas más elevadas, daban variedad al paisaje [...]. A medida que avanzamos, el valle se ensanchaba, permitiéndonos admirar bosques de algarrobos, extensos viñedos y olivos" ${ }^{\text {"35. }}$.

Edward H. Locker (1777-1849) a su paso por el mismo camino el 17 de noviembre de 1813 recibió una impresión similar ante este nuevo panorama que se abre tras abandonar la meseta manchega:

"Cuando llegamos al Puerto de Almansa, donde se dividen los reinos de Murcia y Valencia, contemplamos una comarca que presentaba un contraste muy agradable con las lúgubres y desoladas llanuras de La Mancha. Fue refrescante volver a contemplar esa variedad audaz y animada en la que el intercambio de montaña y valle, rocas y follaje, forman esas espléndidas combinaciones de color y efecto que constituyen el encanto del paisaje" ${ }^{36}$.

A diferencia de otros viajeros, Locker describe con detalle las vistas que contempla a su paso por diversos tramos del camino hasta llegar a Xàtiva. El relato de su guía viene ilustrado con dibujos, por lo que trata de representar en ellos lo pintoresco, en detrimento de otros elementos a los que prestaron atención otros viajeros como los monumentos o las referencias a la historia. Por ello se detiene en Moixent, lugar donde ningún otro viajero fija su atención, cuya descripción literaria sirve para explicar el dibujo que publica con ella:

"El acceso a esta ciudad es muy bello; está situada bajo una elevada cadena de montañas que limita a la derecha del valle; otra cordillera que se extiende a la izquierda, lo que la hace muy atractiva. Moxente está separado de la carretera por un profundo cauce, al fondo del cual discurre un bonito riachuelo

35 TOWNSEND, J. Op.cit., p. 390.

36 LOCKER, E. H., Views in Spain, London, John Murray, 1824. Sin paginar. Traducción propia. 
que desagua en el Xúcar a menos de dos leguas de distancia. Un puente de un solo arco atraviesa el cauce hasta el pueblo: detrás de él se alza una colina sobre la que se levantan las ruinas del castillo árabe. La escena me proporcionó un tema para dibujo que se acompaña"37.

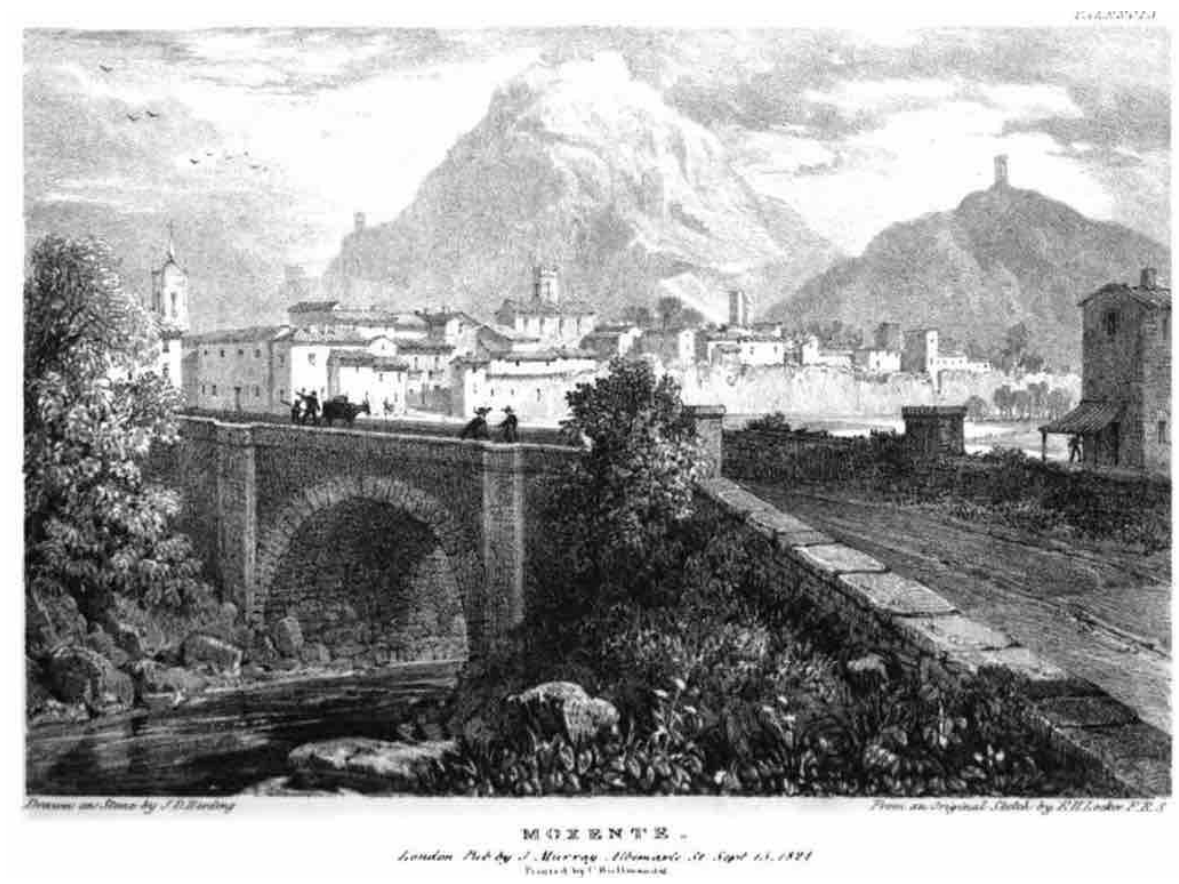

Fig. 2. Moixent. Gravado de James Duffield Harding publicado en Locker, 1824.

Desde Moixent, Locker prosigue el relato de su viaje, donde observa a lo lejos la población de Vallada y las ruinas de su castillo islámico que se alzan sobre las cimas de la montaña:

"El viaje desde Moxente a través de este hermoso valle fue muy gratificante. A medida que avanzábamos, el país parecía aumentar su fertilidad, abundando en aceitunas y algarrobas. La elevada sierra de la derecha presentaba va-

37 Ibídem. 
rias torres en ruinas dispuestas en los salientes más atrevidos, y algunas bonitas aldeas dispersas al pie de ellas" ${ }^{38}$.

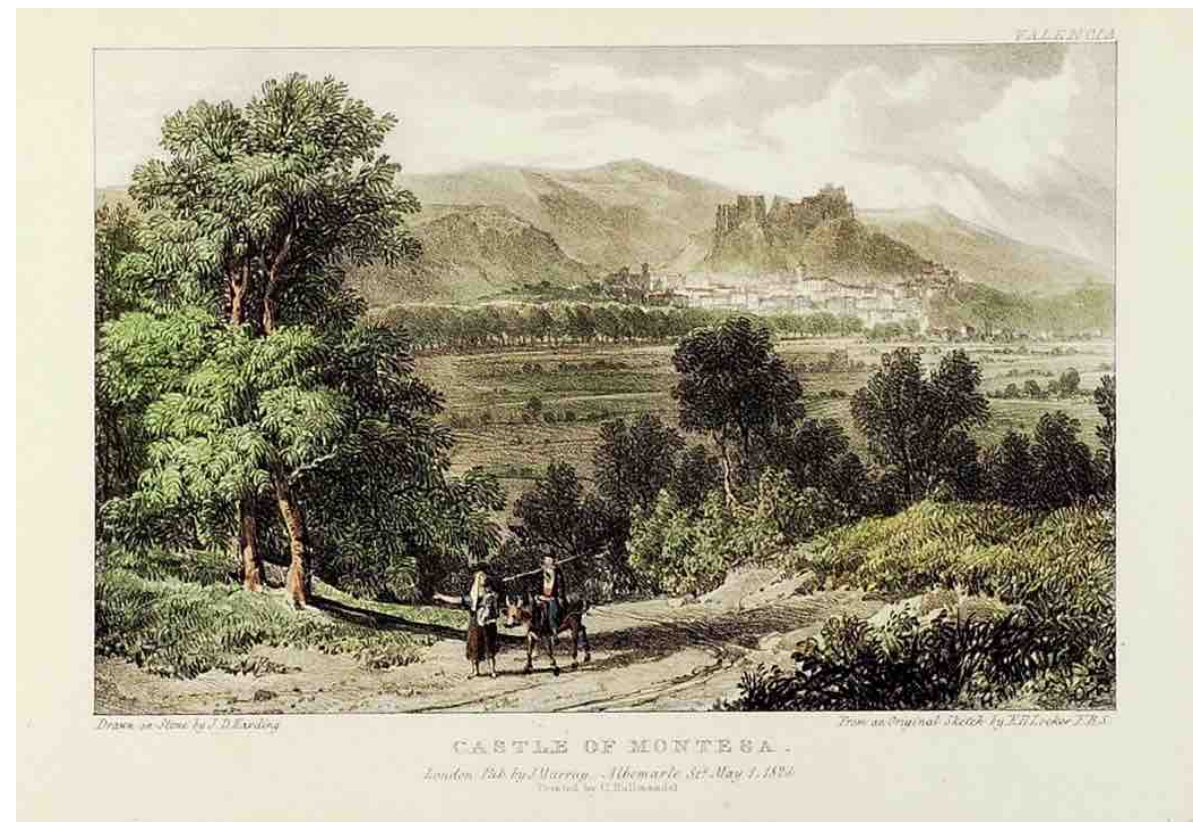

Fig. 3. Castillo de Montesa. Gravado de James Duffield Harding publicado en Locker, 1824. Foto: Biblioteca Valenciana Nicolau Primitiu.

El camino pasa por las inmediaciones de Montesa, que junto con Xàtiva constituyen los principales hitos a los que aluden de forma generalizada los viajeros en su trayecto por el corredor de la Costera. El castillo de Montesa es nombrado por Ponz, Townsend, Ford, Laborde ${ }^{39}$ y el mismo Locker. Todos ellos coinciden en resaltar su valor histórico por su relación con la Orden de Montesa, fundada por el rey Jaime II de Aragón en 1317, y su carácter inexpugnable al estar construido sobre una roca. El edificio se encontraba en un

38 Ibídem.

39 PONZ, A., Viage de España o cartas en que se dan noticia de las cosas más apreciables y dignas de saberse que hay en ella..., Madrid, Imp. Joaquín Ibarra, 1772-1794, vol. IV, p. 317; TOWNDSEND, J., Op. cit., p. 390; FORD, R., A handbook for travellers in Spain and Readers at Home describing the Country and Cities, the Natives and their manners with notices of spanish history, London, John Murray, 1845. Hemos consultado la traducción al castellano publicada bajo el título: Manual para viajeros por los reinos de Valencia y Murcia y lectores en casa, Madrid, Turner, 1982, p. 108.; LABORDE, A., Op. cit., 1806-1820, vol I, p. 95; LABORDE, A., Op. cit, 1826, p. 66. 
estado de ruina causado de forma fortuita por un terremoto acaecido de 23 de marzo de 1748. De esta manera, "este bloque imponente que había detenido ejércitos, no se ha podido defender contra los caprichos de la naturaleza" A pesar de los signos de destrucción, se valoran las ruinas totalmente abandonadas por su monumentalidad y por su carácter pintoresco, por lo que invitan a entrar en ellas y recorrer los subterráneos y estancias que todavía quedaban en pie. Locker y Laborde les dedican sendas láminas a Montesa, cuyo caserío se dispone "en forma de semicírculo, situado al pie de la vertiente de una colina separado de las montañas. Arriba están los restos de su antiguo castillo y convento" 41 .

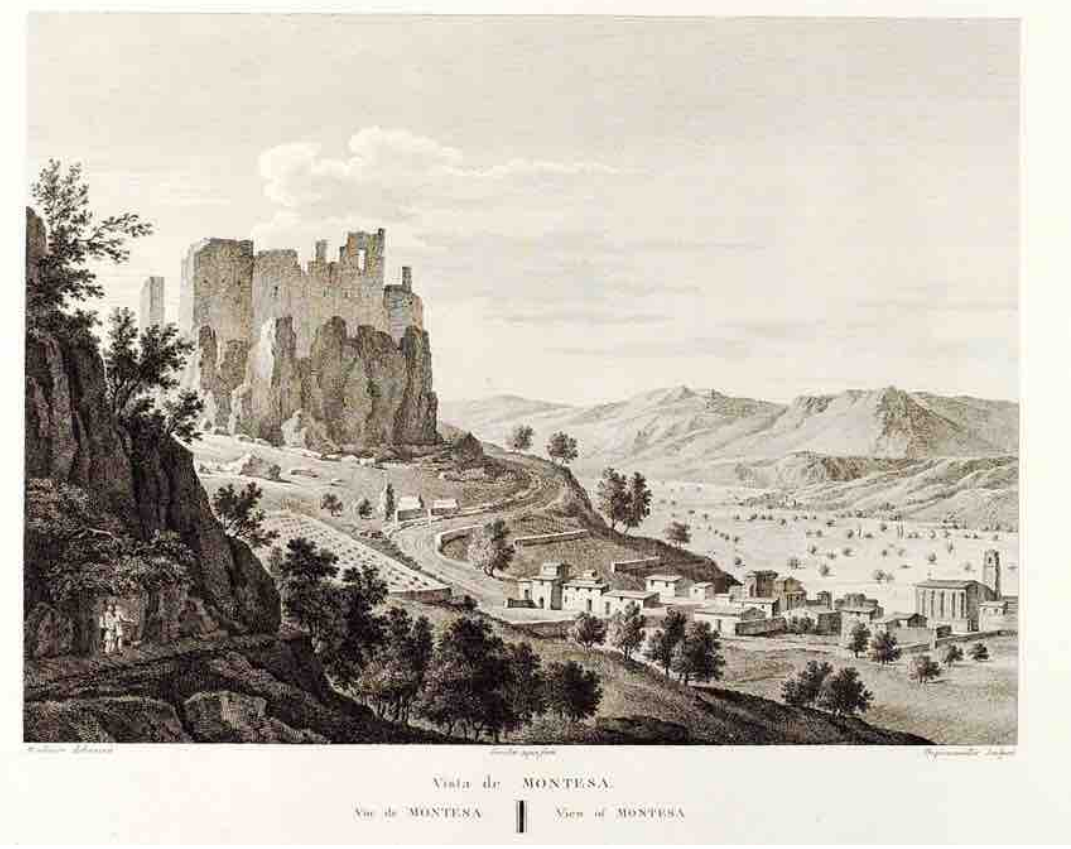

Fig. 4. Vista de Montesa. Gravado de François Jacques Dequevauviller, publicado en Laborde, 1806-1820. Foto: Biblioteca Valenciana Nicolau Primitiu.

40 LABORDE, A., Op. cit., 1808-1809, vol. I, p. 95. Traducción propia.

41 LOCKER, E. H., Op. cit., Traducción propia. 
Tras dejar Montesa el camino se adentra en un entorno que anticipa el panorama que se presentará al pasar sobre las inmediaciones de Xàtiva.

"A ambos lados del camino vimos naranjos, cuyo fruto estaba listo para ser cortado, y aceitunas maduras para la recolección. Las tierras bajas se plantan de arrozales cuidadosamente regados. Casi me imaginé de nuevo en Bengala, porque los trabajadores valencianos son casi tan morenos como los hindúes, a quienes se parecen mucho en sus rasgos"42.

El lugar de Xàtiva es, con toda seguridad, el principal hito del camino. Está formado por el conjunto de la huerta, ciudad y castillo. El Camino Real pasaba a unos cinco kilómetros de la ciudad, lo que equivalía a una hora de trayecto, por lo que su visita se convierte en un acto deliberado que podía responder a diversas motivaciones. Una de ellas era continuar el viaje hacia Valencia por el camino foral para atravesar la Ribera del Júcar por un entorno más agradable a la vista, que contrastaba con los campos de arroz que acompañaban el itinerario por la parte del valle más cercana al río. Tras abandonar Xàtiva, Humboldt decide continuar hacia Valencia por el camino foral dejando la carretera Real,

"a la que sólo nos reincorporamos después del mediodía. Lo que perdimos en comodidad del camino, lo ganamos en la belleza de los parajes que nos rodeaban. Atravesamos la maravillosa huerta de este país y las producciones más maravillosas del sur en su más rica plenitud nos acompañaban constantemente. Especialmente celebrados son los naranjales de Alcira y Carcaxente"43.

También, Henry David Inglis (1795-1835), admirado por estampa romántica que ofrecían las ruinas del castillo, decidió abandonar el Camino Real para conocer de cerca la ciudad de Xàtiva. Tras pasar Montesa,

"poco después, apareció San Felipe a casi una legua de distancia, de manera muy romántica situado en un hueco entre las montañas, con un rico valle que se extiende ante él. La carretera directa a Valencia no pasa por San Felipe: hay un desvío de dos leguas; pero deseaba ver esta bella y antigua ciudad morisca, y se ha arreglado todo para que descanse allí una noche. Por lo tanto, dejamos el camino, y seguí por un camino estrecho a través de la huerta hacia San Felipe, donde llegué por la tarde" ${ }^{\prime 4}$.

42 Ibídem. Traducción propia.

43 HUMBOLDT, W., Op. cit., p. 225.

44 INGLIS, H. D., Spain in 1830, London, S. Manning and Co., 1831, vol. II, p. 318. Traducción propia. A raíz de los decretos de Nueva Planta promulgados por Felipe V, la ciudad de Xàtiva 


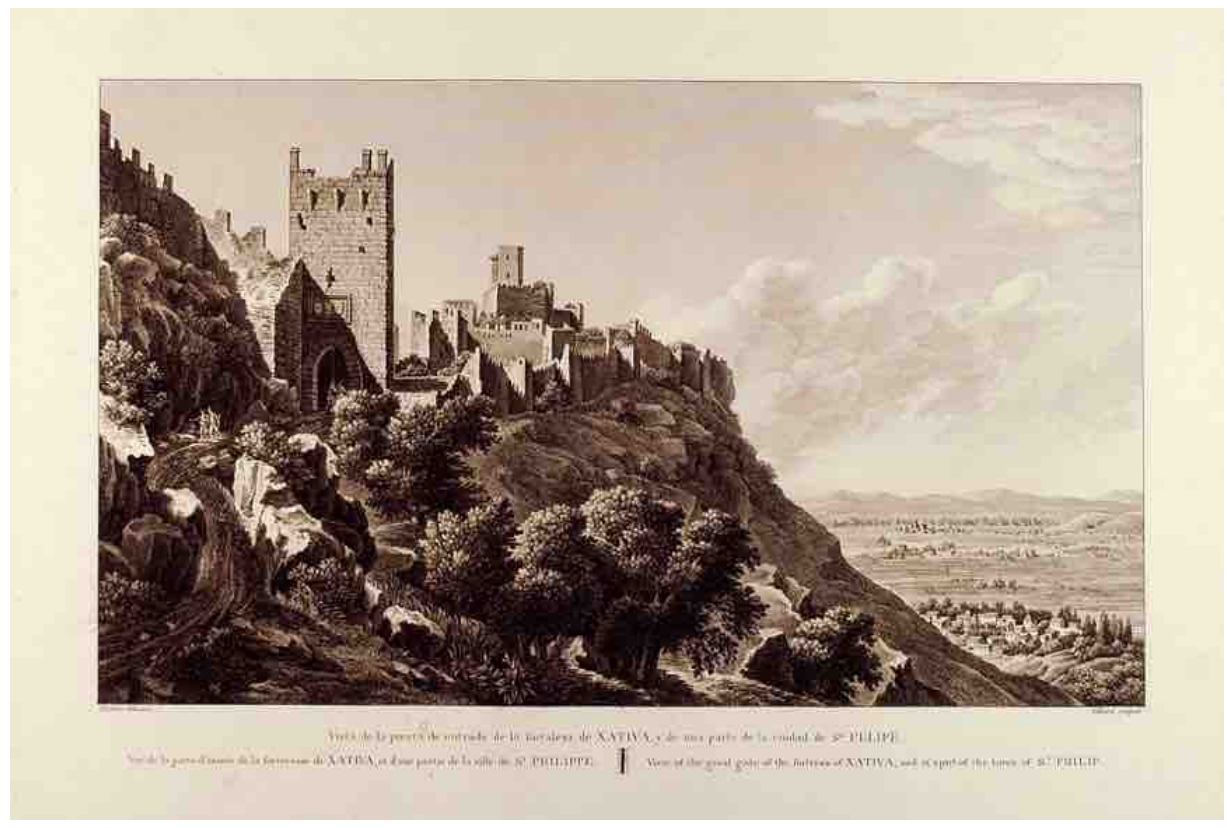

Fig. 5. Vista de la puerta de entrada a la fortaleza de Xátiva. Gravado de Jean-Baptiste Tillard, publicado en Laborde, 1806-1820. Foto:

Biblioteca Valenciana Nicolau Primitiu.

Sin embargo, aquellos viajeros que decidían continuar por el Nuevo Camino Real, al llegar a la cima del puerto de Càrcer y durante su descenso podían contemplar el delicioso panorama de la huerta del Júcar, que se prolonga sin solución de continuidad hacia la del Turia, que envuelve la ciudad de Valencia y que acompaña el camino hasta Sagunto. Townsend, tras visitar Xàtiva, se incorpora de nuevo al Camino Real desde Rotglà. Tras el ascenso del puerto, "desde la cima de estas montañas se domina un dilatado panorama que incluye el rico valle de Valencia" 45 . Más detallada es la descripción que nos ofrece Alexandre Laborde de este mismo recorrido y de las deliciosas vistas que se contemplan desde la cima del puerto:

cambió su nombre por el de San Felipe por haber tomado partido a favor del Archiduque Carlos en la Guerra de Sucesión. En 1811 las Cortes de Cádiz restituyeron su nombre anterior.

45 TOWNSEND, J., Op. cit., p. 391. 
"Desde allí, dejando a la derecha la ciudad y vega de Játiva, se sube insensiblemente el puerto de Cárcer, cuyas montañas están abiertas con tanta igualdad, que se atraviesan en cincuenta minutos, por un camino muy bueno y construido con mucha inteligencia; y a las dos terceras partes de este paso hay una fuente con dos caños, muy agradable a los viajeros, y un pilón para beber las caballerías.

Quando se llega a su altura, se dilata la vista por un valle de grande extensión poblado de multitud de casas, que aunque cubierto de árboles, no recrea la vista como los anteriores; pues estando destinado al cultivo del arroz, su fondo sombrío y obscuro le da cierto aire de tristeza. Atraviésale un camino recto que conduce al Xúcar, río que se pasa en una barca, después de haber dejado a la derecha los lugares de Manuel, y a la izquierda los de Sumacárcer, Benejida y otros muchos, que no deja ver la espesor y multitud de árboles.

El río Xúcar no es de ordinario muy caudaloso; pero se engruesa en las grandes lluvias, y sale de madre e inunda muchas veces el valle y llanura vecina hasta cubrir el camino, aunque está muy alto: por cuyo motivo se han colocado de trecho en trecho muchas columnas de piedra, que guíen el viagero en los tiempos de inundación. Poco después de pasado el río se ve a mano derecha el magnífico puente que construyó en seco el arquitecto Don Joaquín Martínez en el año 1800, con el objeto de mudar el cauce del río, cosa que por las circunstancias de los tiempos no ha podido todavía verificarse, y cuya falta es muy sensible a los pasageros.

Así se entra en la inmensa llanura que termina en los montes de Sagunto, la qual es de una riqueza infinita, y no parece sino una serie de jardines"46.

En sentido contrario, el camino desde Valencia hacia Castilla discurre por una fértil llanura que, salvado el obstáculo del puerto de Càrcer, se prolonga en la vega de Xàtiva. Su feracidad se va diluyendo a la vez que se va estrechando el valle conforme avanza el recorrido hasta llegar a la meseta alicantina o castellana, tras vadear la barrera de montañas que se sitúa a la altura de la Font de la Figuera.

46 LABORDE, A., Op. cit., 1826, pp. 67-68. 


\section{EL VIAJE EN FERROCARRIL}

La inestabilidad que caracterizó la vida política de la España de los años treinta del siglo XIX no resultó propicia para la materialización de propuestas tempranas para la construcción de los primeros trazados ferroviarios en el territorio peninsular. La mayor estabilidad de la siguiente década favoreció que las nuevas peticiones de concesiones pudieran ser consideradas por el Estado, quien encargó a propósito un informe a una comisión presidida por Juan Subercase. Buena parte de sus aportaciones fueron incorporadas a la RO. de 31 de diciembre de 1844, que regularía las primeras líneas que entraron en servicio. Posteriormente, la Ley General de Ferrocarriles de 1855 definió el marco normativo por el que se rigió la construcción de la red principal ${ }^{47}$.

La implantación del ferrocarril en España se realizó por compañías privadas que recibieron concesiones por parte del Estado. Como tales, buscaron obtener la máxima rentabilidad a sus inversiones, lo que fue determinante a la hora de elegir los itinerarios y de materializar sus trazados. Esta es una de las razones que justifica que la red arterial ferroviaria coincida con el trazado principal de la red de caminos. El notable desarrollo que estaba adquiriendo el cultivo y comercio de la naranja en las poblaciones de la comarca de la Ribera Alta explican, entre otros factores, la temprana creación de la Sociedad del Ferrocarril del Grao de Valencia a Játiva en 1851, con la finalidad de acercar estos productos al puerto de Valencia, como puerta de salida hacia los mercados europeos ${ }^{48}$. Las obras de la línea se concluyeron a finales de 1854. Por otro lado, la compañía había adquirido en 1852 la concesión para alargar la línea entre Játiva y Almansa, cuyas obras se ejecutaron entre 1856 y 1859 , con lo que enlazaba con la línea de Madrid a Alicante que explotaba la compañía MZA. A partir de allí obtuvo la concesión entre Valencia y Tarragona, a donde llegó en 1868, y continuó su prolongación hacia el norte hasta alcanzar la frontera francesa a través del paso fronterizo de Port Bou en $1878^{49}$.

La comunicación entre Valencia y Madrid se establecía de nuevo por Almansa, a través del corredor de la Costera, y no por el camino más corto que se dirigía hacia el oeste por Cuenca, por las enormes dificultades topográ-

47 COMÍN COMÍN, F. et alii, 150 años de historia de los ferrocarriles españoles, Madrid, Fundación de los Ferrocarriles Españoles, 1998, vol 1. Ver capítulos 1 y 2.

48 VIDAL OLIVARES, J., "Los ferrocarriles y la expansión comercial agraria valenciana, 1852-1914", en AGUILAR CIVERA, I. y VIDAL OLIVARES, J. (coords.), 150 años de ferrocarril en la Comunidad Valenciana. 1852-2002, Valencia, Generalitat Valenciana. Conselleria d'Obres Públiques, Urbanisme i Transport, 2002, pp. 51-66.

49 AGUILAR CIVERA, I., Estaciones y ferrocarriles valencianos, València, Consell Valencià de Cultura, 1995. 
ficas a que se tenía que hacer frente, lo que encarecía notablemente la construcción ${ }^{50}$. En este sentido resulta también significativo que su recorrido se proyectara en paralelo al antiguo camino foral y no al Nuevo Camino Real pues, como hemos explicado, estas localidades disponían de mayor población y de una agricultura mucho más próspera, orientada al mercado, con lo que se aseguraba la rentabilidad de la inversión. De esta manera se evitaba también enfrentarse al obstáculo que planteaba el puerto de Càrcer, al quedar apartado de su trazado.

El ferrocarril vertebró la primera red de transporte de personas y mercancías a nivel estatal, que se vio complementada posteriormente con el desarrollo de los sucesivos planes de carreteras a partir de 1860. Por ello, durante la segunda mitad del siglo XIX el camino de hierro fue sustituyendo a la carretera en los itinerarios de las guías y libros de viajes de autores locales y extranjeros. Este nuevo medio de locomoción incorpora a la visión pintoresca de los paisajes que ya habían sido descritos desde la carretera, la atención a las grandes obras de fábrica que acompañan la línea férrea. Túneles, desmontes, terraplenes y viaductos son vistos con admiración y presentados como símbolos del progreso, como monumentos de la ingeniería y de la técnica modernas. La llegada del ferrocarril comienza a transformar la imagen de las ciudades, lo que se percibe de forma especial en el caso de Xàtiva, y es vista por algunos autores como una oportunidad para el desarrollo industrial y económico, tal como auguraba Vicente Boix ${ }^{51}$.

Tal vez, la obra más significativa del trazado del ferrocarril entre Almansa y Valencia fue el túnel de Mariaga, que atraviesa el monte del Caputxó que separa el corredor de la Costera de la meseta de Almansa. Los caminos y carreteras superaban las barreras naturales con el ascenso a las mismas para conseguir pasar al otro lado. Trataban de adaptar su trazado sinuoso a la orografía de la montaña con curvas cerradas y suaves pendientes para facilitar el tránsito de los carruajes a escasa velocidad. La mayor velocidad del ferrocarril y sus características precisaron de trazados de escasa pendiente con curvas muy abiertas. Por ello su recorrido se superpone al terreno sirviéndose de desmontes, terraplenes, viaductos y túneles. Las palabras de Teodoro Llorente (1836-1911) explican esta diferente relación con el paisaje que se establece entre carretera y ferrocarril a la hora de abordar el paso a la llanura manchega a través de la sierra del Caputxó en la Font de la Figuera.

50 Una primera fase de esta línea unió Valencia con Utiel en 1887. Pero el trazado hasta Madrid no entró en servicio hasta 1947.

51 BOIX, V., Xàtiva: Memorias, recuerdos y tradiciones de esta antigua ciudad. Xàtiva, Imp. Blas Bellver, 1857, p. 5. 
"La carretera, inclinándose á la derecha, faldea por aquella parte el Capurucho, y por el puerto de Almansa baja a la llanura castellana. La locomotora, más atrevida, embiste por la izquierda la montaña, la agujerea por el túnel de Mariaga, y cuando sale á la otra parte, se encuentra en los límites de las provincias de Alicante y Albacete, Villena a un lado y Almansa al otro"52.

Germond de Lavigne (1814-1896) realizó su viaje poco antes de 1859, y por ello fue uno de los primeros que relata su recorrido en tren desde Alicante a Valencia, donde presta atención de túneles que atraviesan las elevaciones existentes a la altura de la Font de la Figuera.

"La vía pasa por debajo de la montaña de Mariaga, a través de un túnel de 1.514 metros de longitud, circunvala la ladera de la montaña, y entra de nuevo en galería, en un tramo de 278 metros, por debajo de la de Santa Bárba$\mathrm{ra}^{\prime \prime 5}$.

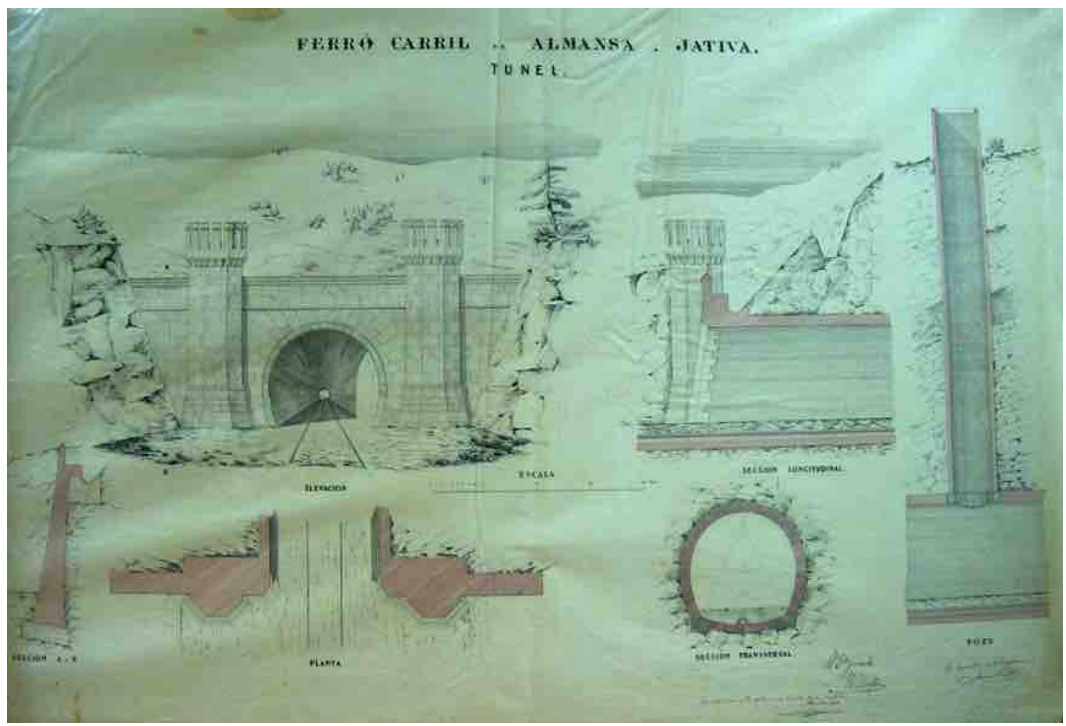

Fig. 6. Ferrocarril de Almansa a Xàtiva. Tunel de Marriaga, 1855. A.H.M.F.

52 LLORENTE OLIVARES, T., España. Sus monumentos y arte. Su naturaleza e historia. Valencia, Barcelona, D. Cortezo, 1885-87, vol. II, pp. 759-760.

53 GERMOND DE LAVIGNE, A., Itinéraire descriptif, historique et artistique de l'Espagne et $d u$ Portugal, Paris, Hachette et Cie, 1859. Traducción propia. Un año antes había publicado un breve estudio sobre los ferrocarriles en España: Les chemins de fer espagnols, Paris, Impr. de Hennuyer, 1858, lo que puede justificar la especial atención que este autor dedica a la descripción de las principales obras de fábrica y la detallada información técnica que aporta. 
El túnel de Mariaga fue proyectado por el ingeniero Domingo Cardenal dentro de la línea Xàtiva-Almansa. En su momento fue el túnel más largo de los que se habían construido en España, por lo que constituye una obra excepcional en la historia de la ingeniería. En un primer momento en el que la obra de ingeniería no tiene referentes estéticos por su novedad, se recurre a la arquitectura. De esta manera, la boca del túnel se acompaña de una estructura construida a modo de embocadura o fachada para resaltar la única parte visible de la obra que se integra en el paisaje ${ }^{54}$. Siguiendo los gustos de momento diseña la boca del túnel en forma de castillo medieval, cuya imagen da entrada a la oscuridad de una gruta o cueva inexpugnable ${ }^{55}$. Como en otras obras de ingeniería del momento se fusiona la novedad y modernidad del nuevo medio de transporte con la imagen del pasado, en este caso de lo medieval, dentro del contexto del romanticismo.

Atravesar una barrera de montañas por medio de un túnel de cierta longitud produce en el viajero unas sensaciones que difieren bastante del itinerario superficial. El paso por un canal oscuro, donde se pierde la noción del espacio, y la aparición repentina de un nuevo paisaje acentúa el efecto sorpresa. Este queda atenuado en el recorrido superficial donde se van intuyendo los cambios entre el panorama que se divisa entre una y otra vertiente conforme se va ascendiendo hacia la cima. Además, la sensación de inquietud e inseguridad que provoca el desplazarse a través de la oscuridad se compensa al salir de nuevo a la luz con un panorama siempre sorprendente ${ }^{56}$. Estas impresiones las refleja Germond de Lavigne (1814-1896) al atravesar los recién construidos túneles de Mariaga y de Santa Bárbara, donde se presenta a la vista un delicioso paisaje que contrasta con la aspereza y monotonía de la meseta del Vinalopó que se contemplaba antes de su entrada.

54 Como explica NÁRDIZ ORTIZ, C., "Otra mirada a la carretera. La relación con el territorio atravesado o construido", Revista de Obras Públicas, n 3540, 2013, pp. 7-20, p. 11, la presencia del túnel como obra de ingeniería es bastante más discreta que la del viaducto o puente, pues este es claramente percibido como un hito visual. Sin embargo, el túnel solo deja ver las bocas de entrada y de salida, pues el resto de la obra permanece oculta bajo tierra.

55 AGUILAR CIVERA, I., "El ferrocarril en la costera. historia, presencias y vestigios de sus estaciones e infraestructuras", en AGUILAR CIVERA, I. (dir.), Historia del ferrocarril en las comarcas valencianas. La Costera, Valencia, Conselleria d'Infraestructures i Transports, 2004, pp. 113-134, p. 129. Se trata de un diseño bastante habitual en los túneles proyectados y construidos en el momento, como se observa en algunos ejemplos conservados que se recogen en: MELIS MAYNAR, M. (dir), Inventario de túneles ferroviarios de España, Madrid, Fundación de los Ferrocarriles Españoles; Ediciones Doce Calles, 2005. En el caso del túnel de Mariaga, el diseño proyectado por Domingo Cardenal no se llegó a ejecutar.

56 AGUILAR CIVERA, I, Op. cit., 2004, p. 129, publica la crónica de la inauguración del trayecto ferroviario entre Almansa i Xàtiva en el Diario Mercantil de Valencia (22-11-1859), en la que se describen las sensaciones que experimentaron las personas invitadas a su paso por el túnel de Mariaga. 
"Al salir de este túnel, te encuentras de repente frente a la magnífica campiña del Reino de Valencia, dominada por el ferrocarril desde un punto bastante alto. En todos los lados hay hermosos cultivos, arrozales cuyo riego es admirable, olivares alineados a soga. La vista reina, casi despejada hasta Valencia, a una distancia de 100 kilómetros" 57 .

Desde la salida del túnel de Santa Bárbara la vía desciende suavemente por el valle de Montesa para salvar la diferencia de altura existente con la meseta alicantina, donde llaman la atención del viajero los diversos terraplenes y puentes que se han tenido que proyectar para poder lograr este desnivel gradual, necesario en los trazados del ferrocarril.

"La diferencia de nivel entre Almansa y Valencia es de 660 metros. Todavía hay casi 600 metros a la salida del túnel de Santa Bárbara. Para compensar gradualmente esta diferencia de nivel, la pista desciende, en pendientes de 10 a 12 milímetros, por enormes terraplenes que atraviesan el campo a 12, 14 y 16 metros de altura, y por puentes de chapa de hierro de gran luz, dispuestos sobre los numerosos barrancos que atraviesan el país"58.

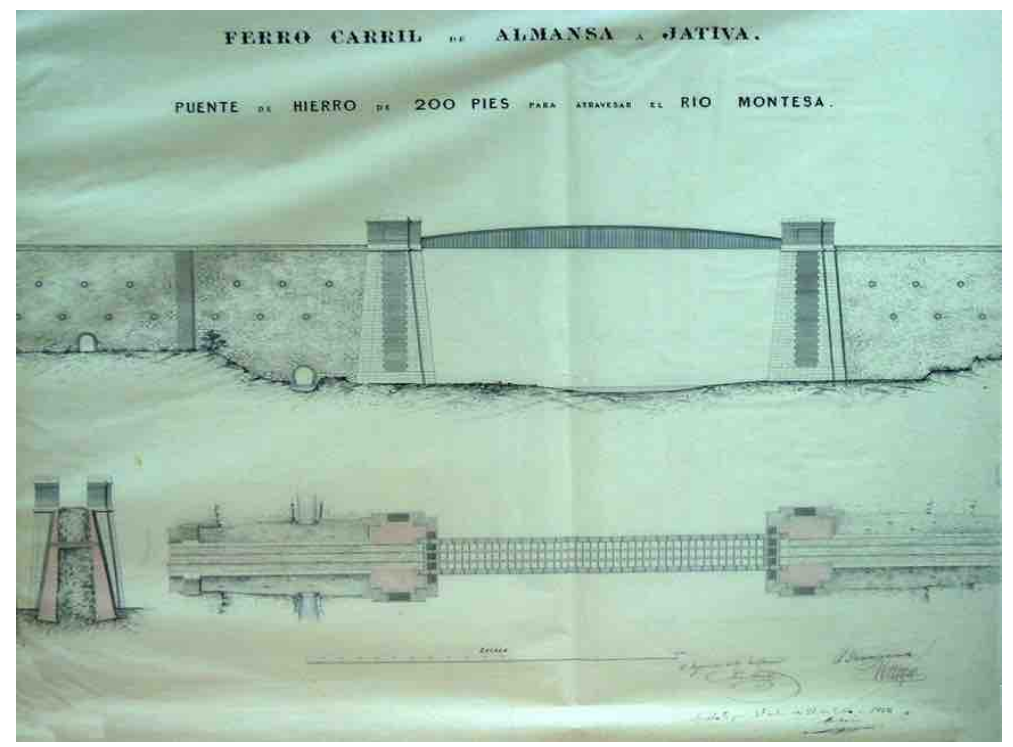

Fig. 7. Ferrocarril de Almansa a Xàtiva. Proyecto del puente de hierro de Montesa mayor, 1855. A.H.M.F.

57 GERMOND DE LAVIGNE, A., Op. cit., p. 324. Traducción propia.

58 Ibídem. 
Los puentes son obras de ingeniería concebidas para cruzar el vado y posibilitar la acción de extenderse en el camino. A lo largo de la historia eran conocidos los puentes de fábrica de piedra y arco, que apoyaban en diversas pilas en relación a su longitud. La mayor velocidad alcanzada por el ferrocarril condicionó que tuviera que abordarse el paso a una altura superior, lo que planteó la necesidad de estructuras capaces de cubrir luces más anchas, por lo que se adoptaron los puentes de viga. Constituyeron una auténtica novedad que causó la admiración de los viajeros, por lo que los más destacados se convirtieron en hitos que llamaron su atención. Muchos de los puentes de mayor luz del tramo Valencia-Xàtiva fueron construidos en madera a partir de las experiencias previas existentes con este material. Pero como consecuencia de diversos incendios fueron progresivamente sustituidos por otros metálicos que ofrecían una mayor durabilidad y resistencia. El de Montesa mayor, proyectado por Domingo Cardenal, fue construido en hierro, obra que Germond de Lavigne destacaba por su mayor monumentalidad y dimensiones. Según explica, cruzaba el cauce del barranco del mismo nombre; "un magnífico puente metálico de 56 metros de longitud, de una sola pieza, llevado sobre dos pilas de granito de $24 \mathrm{~m}$. de altura", que calificó como "obra capital de la línea"59. Tras dejar Xàtiva se refiere a otros puentes construidos en madera. El de Montesa menor, cuya rambla "cruza de nuevo sobre un puente de madera de sistema Town, con aspas cruzadas, formando seis arcos de 16 metros cada uno". A continuación cruza el torrente del Carraixet "sobre un puente del mismo sistema con dos arcos" y más adelante el río Albaida "sobre 7 arcos de 17 metros" $"$, antes de llegar a Manuel, primera localidad de la comarca de la Ribera.

Con anterioridad a 1864 todos los puentes de mayor luz eran de viga metálica de alma llena, proyectados también por Domingo Cardenal, mientras que los de menor luz se construyeron con arcos de ladrillo. Pero estas estructuras metálicas tuvieron poca vida útil, pues fueron completamente destruidas a raíz de la célebre riada de San Carlos como consecuencia de las grandes precipitaciones registradas durante los días 3 y 4 de noviembre de 1864 . Según la Memoria de la inundación del Júcar... se destruyeron los puentes de la Boquilla, formado por un arco de $8,36 \mathrm{~m}$ alzado a $26 \mathrm{~m}$ del fondo del barranco; de las Huertas con un arco de ladrillo de 5,60 m de luz sobre estribos de piedra; del Toll, configurado por una viga de hierro de $18 \mathrm{~m}$ de luz apoyada sobre dos estribos de $15 \mathrm{~m}$ de altura; el referido de Montesa, articulado por

59 GERMOND DE LAVIGNE, A., Op. cit., p. 325. Traducción propia.

60 Ibídem; AGUILAR CIVERA, I., Op. cit., 2004, p. 131, aporta diferentes noticias referentes al proyecto y construcción de este puente. 
una viga de $56 \mathrm{~m}$ de luz; el segundo de Montesa, compuesto por seis tramos de palastro de 15,88 m de luz; y el del río Albaida, que constaba de ocho tramos de hierro asentados sobre pilas y estribos de sillería, formando una luz total de 131, $24 \mathrm{~m}^{61}$. Muchos de ellos perecieron al colapsar las pilas y estribos que los soportaban por no poder resistir los embates de la corriente y los arrastres. Para restablecer el tránsito de la línea fueron sustituidos por unas estructuras provisionales de madera, que son las mismas que llegó a contemplar Valérie Boissier, condesa de Gasparín (1813-1894), durante su viaje desde Xàtiva hacia la Font de la Figuera el 19 de abril de 1867. A diferencia de la admiración suscitada por los puentes metálicos, estas atrevidas estructuras provisionales produjeron en la condesa una sensación de inquietud.

“Andamiados provisionales suplen á los viaductos destruidos; y temo que este provisionalismo no dure más que la vida de los viageros. De lejos asustan aquellas ligeras empalizadas, y parece tan imposible que pase por ellas el tren, como lo sería sostener á un elefante en un camino de alambres; nos acercamos y aún nos parece mayor locura; pero llegamos, pasamos felizmente, y respiramos hasta dos leguas más allá, que reaparece el mismo peligro" 62 .

Todos estos puentes dañados fueron finalmente sustituidos por otros proyectados por el ingeniero J. Beatty, formados por vigas de celosía o vigas trianguladas, de mayor ligereza que las vigas de alma llena de los anteriores viaductos de hierro que fueron destruidos ${ }^{63}$. De esta manera, en apenas una década se produce una evolución tecnológica que se materializa en diferentes soluciones para dar respuesta a las necesarias sustituciones como consecuencia de las destrucciones provocadas por accidentes o por catástrofes naturales.

Hallamos referencias a otras trincheras y terraplenes. Germond de Lavigne nombra el tramo que discurre por l'Alcúdia de Crespins, cuando "la vía entra en una trinchera de 5 metros a través de un largo banco de rocas calizas [...], atraviesa el valle de Cerdá por un terraplén de 6 metros" ${ }^{\prime 64}$, para llegar al puente de Montesa. Otros que viajaron en sentido contrario señalan el paso de la vaguada que precede la huerta de Xàtiva, donde a pesar de su esca-

61 BOSCH Y JULIÁ, M., Memoria sobre la inundación del Júcar en 1864 presentada al Ministerio de Fomento, Madrid, Imp. Nacional, 1866, pp. 72-77.

62 GASPARÍN, V. B., A travers de les Espagnes: Catalogne, Valence, Alicante, Murcie, et Castille, Paris, Michel Lévy fréres, 1868. Hemos tomado la cita de la traducción al castellano publicada bajo el título: Paseo por España: Relación de un viage à Cataluña, Valencia, Alicante, Murcia y Castilla, Valencia, Imprenta de José Doménech, 1875, p. 106.

63 AGUILAR CIVERA, I., Op. cit., 2004, p. 131.

64 GERMON DE LAVIGNE, A., Op. cit., p. 325. Traducción propia. 
sa altura, "la locomotora se abisma por una imponente cortadura de piedras, donde retumba el agudo silvato [sic] de aviso" 65 , en cuya salida se contempla la fértil llanura presidida por la ciudad y el castillo setabense. Como también indica Teodoro Llorente, "al llegar a Manuel el ferrocarril, tuvo que cortar un collado, que señala la divisoria entre la llanura sucronense y la setaben$s e^{" 66}$.

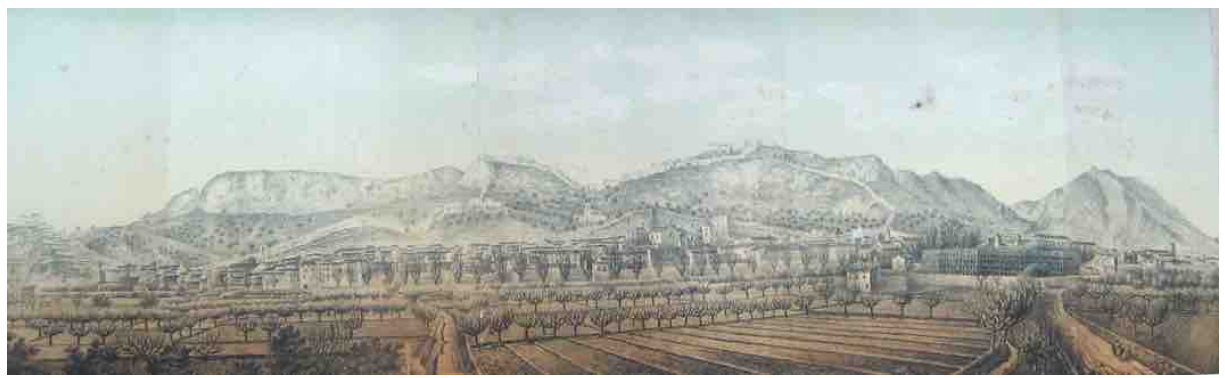

Fig. 8. Vista general de Xàtiva. Xilografía publicada en Boix, 1857.

Llorente describe también con todo detalle el paisaje que se contempla durante el viaje entre Xàtiva y la Font de la Figuera. Al partir de la primera ciudad, "cruza la vía férrea por aquella parte la feraz huerta setabense, arbolada de granados, naranjos y moreras, sobre los que se levantan acá y allá las airosas torres y el apiñado caserio de alegres lugarejos" ${ }^{67}$. Entre l'Alcudia de Crespins y Montesa percibe un cambio en el paisaje, cuando " $\mathrm{el}$ dilatado y hermoso valle se estrecha, los montes se abultan. A uno y otro lado, el cauce del río Cañoles se ahonda, las huertas se achican, formando pequeños bancales en su fondo, y por los declives se extienden en escalonados campos el viñedo y el arbolado de secano" ${ }^{68}$. Pasado Moixent los cerros continúan estrechando el valle "hasta que aparece, se eleva y agiganta una pirámide colosal, que parece colocada alli para cerrar el paso y servir de mojón entre los reinos de Valencia y Castilla. Danle aqui el nombre expresivo del

65 BOIX, V., Op. cit., p. 410.

66 LLORENTE OLIVARES, T., Op. cit., vol II, p. 716.

67 Ibídem, pp. 748-749.

68 Ibídem, p. 751. 
Capurucho. A sus pies esta Fuente la Higuera, último pueblo valenciano por esta parte" 69 .

En la misma línea se expresa Hans Christian Andersen (1805-1875) al recorrer el mismo trayecto en 1862. Tras abandonar la huerta de Xàtiva describe un panorama desolador que acentúa más si cabe el contraste con la fertilidad de la misma.

"Junto a la antigua y moruna ciudad de Játiva, cuyas murallas almenadas dan un aspecto caballeresco al paisaje, se extinguió la huerta valenciana. Fue como si, saliendo de un oasis rebosante de frutas, nos adentrásemos por un desierto de piedra. El sol pegaba con violencia; el suelo pedregoso parecía exhalar el calor retenido del pasado día, con lo cual aumentaba ya el excesivo ardor del aire. Separadas entre sí por infinita distancia, veíanse solitarias las alquerías de los agricultores, cercadas, a modo de fortalezas, por altas tapias que las protegían contra los animales salvajes y contra los malhechores. No se divisaba ni un árbol; el único verde que aparecía a la vista eran algunas chumberas, cuyos tallos hinchados como esponjas asomaban por detrás de los muros y entre las hendiduras de los peñascos del monte. Carros de transporte, cargados hasta los topes, tirados por seis u ocho mulos en fila, prestaban algo de vida a aquel desierto asolado y muerto; diríase que un aluvión se había llevado todo por delante, o que el aire candente había abrasado, brizna a brizna, toda la hierba, llevándose hasta las cenizas" ${ }^{\text {"70 }}$.

69 Ibídem, p. 759.

70 ANDERSEN, H. C., In Spanien, Kjobenhavn, C. A. Reitzel, 1863. Hemos tomado la cita de la traducción al castellano publicada bajo el título: Viaje por España, Madrid, Alianza, 1995, p. 67. 


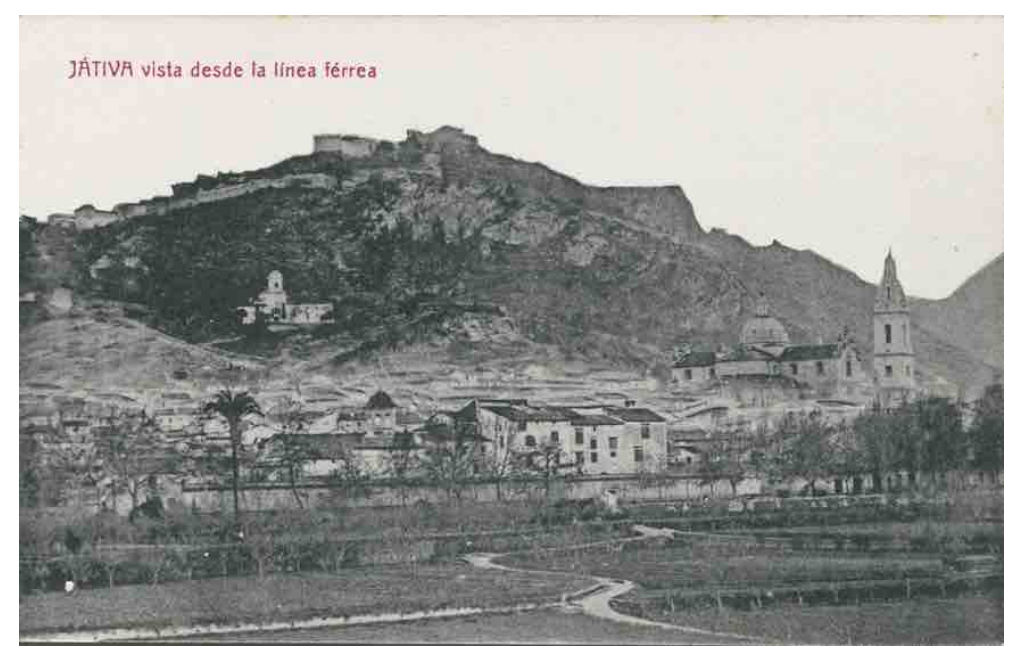

Fig. 9. Xátiva vista desde la línea férrea. Tarjeta postal. Ed. Martínez Bellver, s. a. Biblioteca Valenciana Nicolau Primitiu.

Sin embargo, Edmundo de Amicis (1864-1908) proyecta una visión exagerada respecto a los otros viajeros que percibieron una transición gradual entre el paisaje que se contempla al principio y al final del viaje por el valle de la Costera realizado en 1872, destacando en este caso su absoluta fertilidad en contraste con la meseta castellana que acababa de dejar atrás.

“...después de la llanura de Almansa, se abre un delicioso oasis, una tierra vendecida por Dios, un verdadero paraíso terrestre: el reino de Valencia. Desde sus confines hasta la ciudad, atraviesa uno jardines, viñedos, densos bosques de naranjos, pequeñas villas blancas coronadas de azoteas y alegres pueblos pintados con vivos colores. Uno va paseando entre grupos, hileras y bosquecillos de palmeras, entre granados, áloes, cañas de azúcar, inmensos setos de higos chumbos, largas cadenas de pequeñas colinas y de collados de forma cónica, cultivados como huertos, como jardincillos, con senderos cuidados primorosamente desde la cima hasta el valle, llenos de colores, como grandes ramos de plantas y de flores. Por todas partes, una vegetación que no deja ningún vacío, que supera cualquier altura, que viste toda protuberancia, se eleva, cuelga, se arrastra, se confunde, se amontona, se enreda, os impide ver, os cierra el camino, os deslumbra la vista con su verdor, os cansa con tanta belleza, os confunde con sus caprichos y locuras, y os da la impresión 
de un alumbramiento improvisado de la tierra, encendida de voluptuosa fiebre, por el fuego de un secreto volcán"71.

\section{CONCLUSIONES}

El estudio de los testimonios literarios de los viajeros que desde finales del siglo XVIII recorrieron en Nuevo Camino Real de Madrid y a partir de 1859 viajaron por el ferrocarril desde Xàtiva a Almansa nos ha permitido adentrarnos en el conocimiento de las valoraciones de estas obras públicas y del paisaje circundante a su paso por el valle de la Costera. Por un lado prestan atención a la forma en que estas vías se insertan y se relacionan con el territorio que atraviesan, y especialmente a determinados hitos construidos (puentes, túneles, terraplenes y otras obras de fábrica). Causaron admiración por su novedad, y no pasaron desapercibidos en su momento al ser valorados como viva expresión de los avances de la ingeniería, de la ciencia y de la técnica. Por otro lado, estas vías facilitaron nuevas formas de acercarse al territorio que atraviesan. De manera unánime los diferentes relatos coinciden en presentar el valle de la Costera como un lugar de transición entre dos paisajes con unas características bien definidas y contrapuestas: el de la huerta de Valencia y el de la meseta manchega. La mayor velocidad que imprime el viaje en tren contribuye a acentuar la percepción de este contraste. Por tanto, la principal novedad que aportan los testimonios de los viajeros que hemos presentado respecto los producidos desde el paso por los caminos tradicionales, es que, además de los hitos culturales y naturales de este paisaje, integran también en sus imágenes del viaje las principales obras de fábrica de estas nuevas vías y se convierten, por tanto, en elementos de un nuevo paisaje construido.

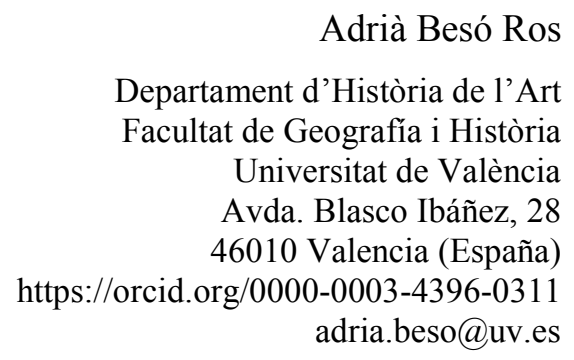

71 AMICIS, E., Spagna, Firenze, G. Barbera, 1873. Hemos tomado la cita de la traducción al castellano publicada bajo el título: España: Diario de viaje de un turista escritor, Madrid, Cátedra, 2000 , p. 340. 
